\title{
The Stimulus for Case-building Activity in Caddis-worms (Trichoptera)'
}

\author{
DOROTHY MERRILL 2 \\ Department of Zoology, The University of Michigan
}

\begin{abstract}
In four species of caddis-worms,-Ptilostomis semifasciata (Say), Platycentropus radiatus (Say), Limnephilus indivisus Walker, and Pycnopsyche guttifer (Walker), - removal of the anal hooks and the posterior hair sensilla significantly prolonged case-building activity with a resulting increase in case production. The extensive building was of the rough provisional type, which is normally completed within a few hours. There were differences among the species with regard to the amount of excessive building and the relative importance of the hairs.

Transection of the ventral nerve cord appeared to block the extensive building that normally followed hook removal.

It is proposed that the stimulus for building is an endogenous process which causes excitatory impulses to be emitted from the several ganglia. The impulses go forward to the integrative areas controlling the animal's building apparatus and stimulate building. The emission of impulses from the ganglia is inhibited by sensory input from contact with the case.
\end{abstract}

Many caddis-worms, or Trichopteran larvae, build portable cases which they inhabit throughout their larval and pupal stages. The cases are constructed of either plant materials or mineral substances which the larva fastens together with silk in a pattern characteristic of the species. Under natural conditions, most larvae build a case immediately upon hatching from the egg, and add to the anterior ends of their cases as larval growth occurs (Betten, '34). If removed from their cases, they can, in general, build new cases. At least one species, however, loses the capacity for starting a new case during its terminal larval stadium (Cummins, '61).

In building a new case, the larva proceeds through two stages. The early, or provisional, stage of building results in a rough irregular structure which provides a covering for the animal and is usually completed within a few hours (Gorter, '29; Fankhauser and Reik, '35). This stage is gradually succeeded by definitive building in which the larva constructs, at a more leisurely pace and with more selectivity of materials, the type of case more characteristic of the species (Gorter, '29; Copeland and Crowell, '37). When the definitive case is large enough for the animal, the larva cuts off the provisional portion at the posterior end and lines the case with silk. Some species build a membrane across the posterior end, leaving a small opening for passage of the respiratory current which the larva creates by undulatory movements of the abdomen (reviews by Betten, '34; Balduf, '39).

This paper will demonstrate that certain posterior structures on the animal, specifically the anal hooks and a group of hair sensilla, are important for the inhibition of building activity when cases have attained adequate lengths. An hypothesis will be presented regarding the mechanisms by which building activity is stimulated and inhibited. A preliminary report has been published (Merrill, '63).

\section{MATERIALS AND METHODS}

\section{A. Collection and maintenance of animals}

Most of the experimental work was conducted with larvae of Ptilostomis semifasciata (Say) (Phryganeidae). These were available from September through March in streams near Ann Arbor, Michigan. On the basis of head diameters (fig. 1) they were separated into four groups representing second through fifth instars. Accord-

\footnotetext{
1 A portion of a dissertation submitted in partial fulfillment of the requirements for the degree of Doctor of Philosophy at the University of Michigan. 2 Present address: Department of Zoology, Smith College, Northampton, Massachusetts.
} 


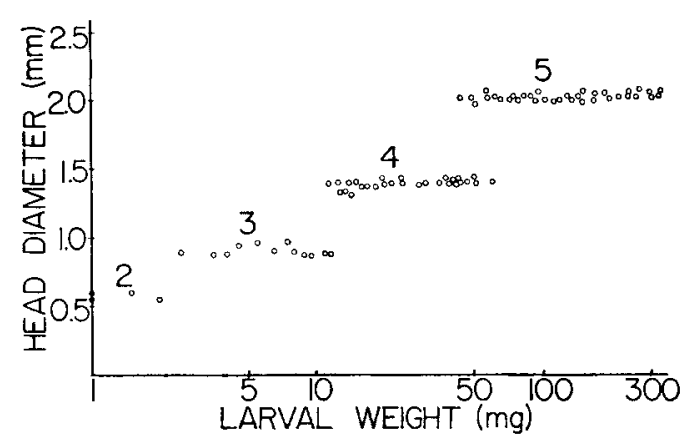

Fig. 1 Distribution of the head diameters of Ptilostomis over the weight range of larvae collected. Stadia 2 to 5 are represented (see text).

ing to Siltala (cf. Betten, '34), the phryganeids have five larval stadia, and first instars lack tracheal gills.

When Ptilostomis larvae were no longer available, three species of Limnephilidae were used to test the effect of removing anal hooks and posterior hair sensilla. These were Limnephilus indivisus Walker, collected from ponds during April and May, Platycentropus radiatus (Say), found in streams from November through April, and Pycnopsyche guttifer (Walker), another stream species available from March through late summer. All of the limnephilids used were in their terminal larval stadium, i.e. they entered pupation on their next molt.

The four species of larvae are shown with their definitive cases in plate 1 , figures 4 to 7 . Identification of the species was based on adults reared in the laboratory.

Stock animals were maintained in the laboratory in a large tank containing aerated tap water and vegetation from the collecting site. Experimental animals were maintained in enamelled pans which were divided into compartments $31 / 2^{\prime \prime} \times 4^{\prime \prime}$ by means of glass partitions and plastic screening. A continuous flow of aerated tap water was circulated through the compartments. Vegetation and dead plant materials were provided for food and building materials.

\section{B. Ablation methods}

Before an operation, the animal was anesthetized in $2 \%$ ether in tap water, transferred briefly to absorbent paper, and weighed. It was then placed on a paraffin block or a wax-bottomed Petri dish and covered with a strip of thin plastic, which was pinned down tightly on either side. The area to be operated was exposed either at the edge of the strip or through a small window. The plastic served the dual purpose of holding the animal in a fixed position and preventing desiccation while the animal was out of water.

The ablations which were performed are listed below.

1. Anal hooks (fig. 2) - The hook was caught on a microscalpel, and forceps were pressed against the opposite side of the hook until it was cut through. This left the shaft of the hook intact and caused very little bleeding.

2. Hair sensilla on the ninth and tenth abdominal segments (fig. 2) - These were simply pulled out, one or two at a time, with fine forceps.

3. Nerve cord transection - This operation was carried out with the larva immersed in perfusion fluid. ${ }^{3}$ A transverse cut was made on the ventral side of the sixth abdominal segment. The nerve cord

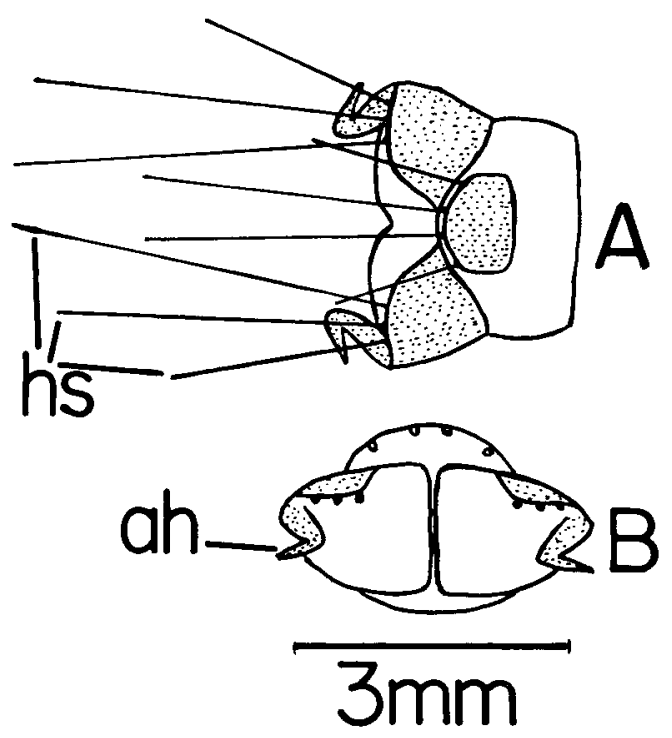

Fig. 2 The ninth and tenth abdominal segments of Ptilostomis. A. Dorsal view; B. Posterior view. Drawn from a fifth instar. Stippling indicates sclerotized regions. ah, anal hook; hs, hair sensilla.

${ }_{3} 130 \mathrm{mM} \mathrm{NaCl}, 10 \mathrm{mM} \mathrm{KCl}, 2 \mathrm{mM} \mathrm{CaCl}, 2 \mathrm{mM}$ $\mathrm{MgCl}_{2}, 4 \mathrm{mM} \mathrm{NaH}{ }_{2} \mathrm{PO}_{4}, 6 \mathrm{mM} \mathrm{NaHCO}_{3}$. 
was lifted to the surface with a glass hook and cut between the sixth and seventh abdominal ganglia. Controls were given cuts in the abdominal wall with probing into the cavity.

Following the operations, the larvae were placed in individual recovery dishes containing an aerated solution of Buffered Penicillin G (Crystalline-Potassium) ${ }^{4}$ in sterile tap water (30 units $/ \mathrm{ml}$ ). Their original cases were placed in boiling water during the operation and transferred to the recovery dishes with the animals. The time in the penicillin varied from 1 to 12 hours depending on the severity of the operation.

After the recovery period, the larvae were removed from their cases, placed in isolated compartments, and provided with building materials. The amount of building activity was checked daily until building ceased.

The larvae which had undergone nerve cord transection were subsequently dissected in order to verify that the nerve cord had actually been severed.

\section{RESULTS}

\section{A. The effect of the removal of the anal} hooks and posterior hair sensilla

When normal larvae were removed from their cases and thereby forced to build new ones, their building activity generally stopped after 2 to 3 days. During this time, the limnephilids produced cases of approximately their own length, i.e., 17$20 \mathrm{~mm}$. Ptilostomis cases were generally longer than the animals, and varied with larval size for animals up to $150 \mathrm{mg}$ in weight (fig. 3). On the average the rebuilt Ptilostomis cases were slightly shorter than the original cases.

The posterior end of the larva is the last portion to be covered when a new case is built. In investigating the problem of why larvae stop building when their cases are large enough, it seemed feasible to test whether a feedback mechanism involving posterior structures might lead to the inhibition of building.

Ablation experiments showed that the anal hooks and the large hair sensilla on the last two segments have a pronounced effect on the duration of building activity and on the length of the cases produced.

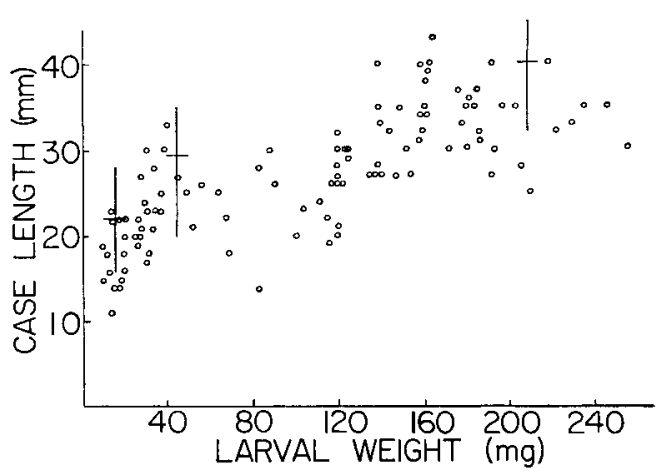

Fig. 3 The length of rebuilt Ptilostomis cases in relation to larval size. Vertical lines indicate length range of original cases for three weight ranges of $10 \mathrm{mg}$. Horizontal lines indicate the weight ranges and are placed at mean length of original cases.

When these structures were removed, the animals continued building at a rapid pace and often produced excessively long cases.

The data for each species are presented below. In the tabulation, the term case production indicates the total length of case built by the larvae. Since many animals cut portions from the posterior ends of their cases and then added more to the anterior ends, the case production for any given larva often exceeded the maximum length that the case attained. In determining the duration of building activity, any day on which a measurable addition was made to the case was counted as one day of building.

The tables show the means and standard deviations of several parameters for each group of animals tested. The range of case production is also given for each group. Statistical significance as determined by the t-test is discussed in the text. The nonparametric Mann-Whitney U test (Siegel, '56) was applied to the raw data as an additional check on significant differences.

\section{Ptilostomis semifasciata}

The comparison between control animals and larvae lacking hooks and hairs is shown in the first two columns of table 1. The average case production in the experimental group was three times that of the controls $(p=0.005)$. Differences in the duration of activity and the final case length were significant at a probability

\footnotetext{
${ }_{4}^{4}$ Eli Lilly \& Co.
} 
TABLE 1

Building activity of Ptilostomis larvae (large fifth instars) following ablation of posterior structures

\begin{tabular}{lcccc}
\hline & Controls & $\begin{array}{c}\text { Hooks and hairs } \\
\text { removed }\end{array}$ & $\begin{array}{c}\text { Hooks only } \\
\text { removed }\end{array}$ & $\begin{array}{c}\text { Hairs only } \\
\text { removed }\end{array}$ \\
\hline No. of larvae & 11 & 8 & 8 & 6 \\
Weight (mg) & $187.4 \pm 29.7$ & $242.9 \pm 36.1$ & $231.2 \pm 39.5$ & $210.5 \pm 36.4$ \\
mm of case production & $36.1 \pm 5.9$ & $115.6 \pm 52.5$ & $89.0 \pm 37.7$ & $34.2 \pm 10.6$ \\
Range (mm) & $27-45$ & $38-195$ & $55-167$ & $18-48$ \\
Duration (days) & $2.3 \pm 0.85$ & $7.1 \pm 4.1$ & $5.6 \pm 2.0$ & $2.0 \pm 0.6$ \\
Final case length (mm) & $31.9 \pm 5.4$ & $89.5 \pm 51.8$ & $55.5 \pm 8.7$ & $31.7 \pm 6.9$ \\
\hline
\end{tabular}

level of 0.01 . The long cases were constructed with fragments of irregular shape and there were many gaps between fragments (plate 1, fig. 8). The inner walls of the long cases were lined with an irregular network of silk fibers, whereas the control cases had a more copious deposit of silk forming a continuous sheet. Thus the extensive building was provisional in nature.

The effects of removing hooks alone or hairs alone are shown in the last two columns of the table. Hook removal caused increases in case production, duration of activity, and final case length, all of which were significant $(\mathrm{p}=0.005)$. Although the averages for this group were lower than for the group lacking hooks and hairs, no significant differences could be established between them. Removal of hairs alone had no effect on building activity. This group of animals did not differ from the controls in any aspect of case-building.

When larvae were allowed to retain their original cases, the effect of hook and hair removal was even more striking. Controls rarely added to their cases, while the experimentals showed the same building range as did animals deprived of their cases. Table 2 summarizes the results for a group of fourth and small fifth instars.
TABLE 2

Building activity of young Ptilostomis larvae (fourth instars and small fifth instars) following hook and hair removal when original cases were retained by the larvae

\begin{tabular}{|c|c|c|}
\hline & Controls & $\begin{array}{c}\text { Hooks and hairs } \\
\text { removed }\end{array}$ \\
\hline No. of larvae & 6 & 10 \\
\hline Weight (mg) & $31.3 \pm 14.1$ & $43.8 \pm 33.7$ \\
\hline \multicolumn{3}{|l|}{$\mathrm{mm}$ of case } \\
\hline production & $2.5 \pm 4.0$ & $67.1 \pm 50.0$ \\
\hline Range ( $\mathrm{mm})$ & $0-9$ & $17-150$ \\
\hline Durataion (days) & $0.5 \pm 0.8$ & $4.4 \pm 1.9$ \\
\hline \multicolumn{3}{|l|}{ Final case } \\
\hline length $(\mathrm{mm})$ & $25.5 \pm 5.8$ & $44.8 \pm 46.3$ \\
\hline
\end{tabular}

Only two controls made additions, while all of the experimentals exhibited building activity.

\section{Platycentropus radiatus}

Table 3 presents the results of ablation in this species. Case production, duration of building activity, and final case lengths were significantly greater in both of the experimental groups than in the control group $(p=0.01)$. There were no significant differences between the animals lacking only the hooks and those lacking both hooks and hairs. The long cases (plate 1,

TABLE 3

Building activity of Platycentropus larvae following removal of anal hooks and posterior sensory hairs

\begin{tabular}{lccc}
\hline & Controls & $\begin{array}{c}\text { Hooks and hairs } \\
\text { removed }\end{array}$ & $\begin{array}{c}\text { Hooks } \\
\text { removed }\end{array}$ \\
\hline No. of larvae & 8 & 5 & 9 \\
Weight (mg) & $178.3 \pm 12.8$ & $183.8 \pm 6.8$ & $185.8 \pm 13.5$ \\
mm of case production & $27.1 \pm 4.8$ & $44.2 \pm 8.1$ & $41.8 \pm 11.6$ \\
Range (mm) & $22-35$ & $35-55$ & $28-67$ \\
Duration (days) & $1.9 \pm 0.37$ & $3.4 \pm 0.86$ & $3.9 \pm 1.7$ \\
Final case length & $20.0 \pm 2.7$ & $37.6 \pm 9.9$ & $34.2 \pm 13.5$ \\
\hline
\end{tabular}


fig. 9) were rather flimsy and had almost no silk fibers deposited on the inner wall.

Limnephilid larvae generally build silk membranes across the posterior end of their cases (Betten, '34). Only three of the animals lacking hooks, and none of those lacking both hooks and hairs constructed such a membrane. Thus, another mark of definitive building was lacking in these animals. Since Platycentropus larvae which had undergone other types of injury, e.g., leg amputations, usually built a membrane, the general failure in membrane construction cannot be attributed to injury per se in the animals lacking hooks and hairs.

\section{Limnephilus indivisus}

Although Limnephilus larvae showed a large increase in case production when both hooks and hairs were removed (plate 1, fig. 10), ablation of hooks alone caused only a small increase. The results are presented in table 4.

The average case production following hook removal exceeded control production by less than $10 \mathrm{~mm}(\mathrm{p}=0.025)$, and only one larva in this group exceeded a production of $39 \mathrm{~mm}$. The slight increase in duration was not significant. Removal of both hooks and hairs resulted in a case production nearly twice that of the "hooks" group $(p=0.01)$, and a concomitant increase in duration $(\mathrm{p}=0.025)$.

Another difference between this and the two preceding species was the fact that these animals eventually made a transition to definitive building. Most of the excessive case length was cut off, and the remaining case was then lined with silk and constricted at the posterior end with a membrane. The portions cut off were poorly constructed and lacked a silk lining.

\section{Pycnopsyche guttifer}

Of the four species studied, Pycnopsyche showed the smallest response to the experimental treatment. Table 5 summarizes the results. Removal of hooks or hairs alone had essentially no effect on building. The slight increase in case production following hook removal was not significant.

When both hooks and hairs were removed, there were slight increases in case production, duration of activity, and final case length, all of which were significant at the 0.01 level. Comparison of this group with the animals lacking only the hooks showed no significant difference in case production.

TABLE 4

Building activity of Limnephilus larvae following removal of anal hooks and posterior sensory hairs

\begin{tabular}{lccc}
\hline & Controls & $\begin{array}{c}\text { Hooks and hairs } \\
\text { removed }\end{array}$ & $\begin{array}{c}\text { Hooks } \\
\text { removed }\end{array}$ \\
\hline No. of larvae & 14 & 11 & 13 \\
Weight (mg) & $92.9 \pm 17.3$ & $95.8 \pm 17.1$ & $\mathbf{8 6 . 6 \pm 1 8 . 1}$ \\
mm of case production & $23.9 \pm 4.4$ & $63.2 \pm 32.1$ & $33.4 \pm 17.0$ \\
Range (mm) & $17-33$ & $17-120$ & $20-88$ \\
Duration (days) & $2.6 \pm 0.7$ & $5.0 \pm 2.1$ & $3.3 \pm 1.3$ \\
Final case length (mm) & $18.4 \pm 2.3$ & $24.2 \pm 4.7$ & $23.5 \pm 2.7$ \\
\hline
\end{tabular}

TABLE 5

Building activity of Psycnopsyche larvae following removal of anal hooks and posterior sensory hairs

\begin{tabular}{lcccc}
\hline & Controls & $\begin{array}{c}\text { Hooks } \\
\text { removed }\end{array}$ & $\begin{array}{c}\text { Hairs } \\
\text { removed }\end{array}$ & $\begin{array}{c}\text { Hooks and hairs } \\
\text { removed }\end{array}$ \\
\hline No. of larvae & 10 & 6 & 8 & 9 \\
Weight (mg) & $146.2 \pm 27.8$ & $161.3 \pm 26.6$ & $134.9 \pm 50.7$ & $143.1 \pm 49.8$ \\
mm of case production & $30.9 \pm 5.5$ & $35.0 \pm 8.6$ & $29.6 \pm 7.1$ & $38.3 \pm 5.3$ \\
Range (mm) & $23-41$ & $24-45$ & $22-42$ & $30-49$ \\
Duration (days) & $3.6 \pm 1.4$ & $3.8 \pm 1.0$ & $3.9 \pm 1.2$ & $5.9 \pm 0.6$ \\
Final case length $(\mathrm{mm})$ & $19.5 \pm 2.8$ & $21.0 \pm 3.5$ & $18.8 \pm 3.4$ & $26.4 \pm 5.1$ \\
\hline
\end{tabular}


Like Limnephilus, most of the Pycnopsyche larvae lacking hooks and hairs eventually produced cases with definitive characteristics. The long Pycnopsyche case shown in plate 1 , figure 11 , lacks the projecting twigs that characterize definitive cases of this species. It did, however, have a posterior membrane and a fairly copious lining of silk.

The extensive building which followed hook and hair removal indicates that these posterior structures do play a role in the inhibition of building activity when cases are large enough for the animals. Clearly there are differences among the species with regard to the relative importance of the hairs and to the amount of excessive building which followed ablation.

\section{B. The effect of nerve cord transection}

It became a matter of interest to determine at what level of the nerve cord the apparent inhibitory action of the hooks and hairs was effected. I initially assumed that the sensory impulses from these structures were transmitted up the nerve cord to the thoracic and/or head ganglia which control the animal's building apparatus. If this were true, then transection of the nerve cord might have an effect comparable to hook and hair removal. However, Diehm ('49) reported that when the nerve cords of Neuronia ruficrus larvae were transected behind the fifth or sixth ganglia, the survivors ( 5 out of more than 50 operated) built cases that extended only as far as the cut, leaving the posterior end exposed.

I tested two groups of Ptilostomis larvae, cutting the cord between the sixth and seventh ganglia. The survival rate was nearly $100 \%$. Since the last ganglion was undamaged, hook activity was still present, and all of the animals were observed clinging to the case wall with the hooks when placed temporarily in paper cases.

In the first group there were no significant differences between experimentals and controls in either case production or the nature of the cases.

The larvae in the second group were tested in several ways following the operation. Table 6 shows the tests and their results.

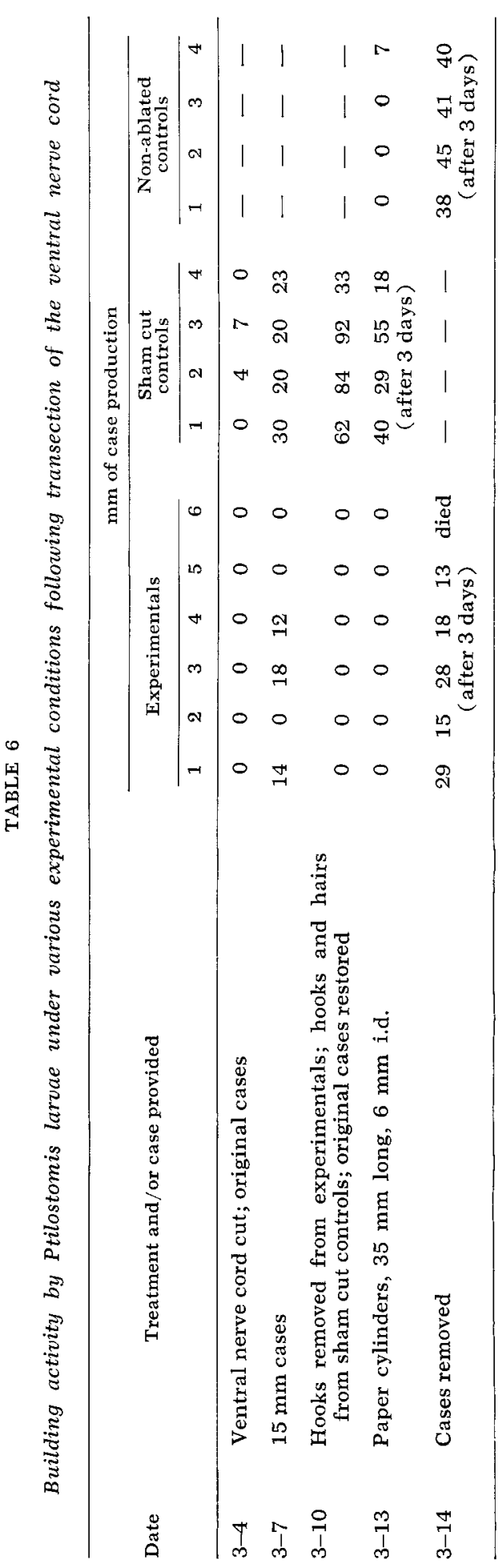


The experimentals showed, if anything, a reduced tendency to build. The additions made to the short cases were sufficient to cover the animals but were less than those made by the controls. Hook removal did not induce the building activity that would occur with an intact nerve cord. Several of the animals were frequently observed with their posterior ends protruding from the cases.

The last four segments of the experimental larvae were slightly swollen after the operation. Since it was possible that the swelling caused enough friction against the case to provide some anchorage of the animal's posterior end, the larvae were provided with paper cases of slightly larger diameter. In these it could be observed that there was no anchorage by friction. Nevertheless the animals did not build.

Removal of the cases established that the animals still retained the capacity for building. The five survivors built new cases which averaged less than normal length.

It must be concluded, therefore, that the sensory impulses from the hooks and hairs do not have to reach the anterior regions of the nerve cord in order to exert their effect on building activity. The possibility that abdominal stretch receptors (Osborne and Finlayson, '62) could detect hook attachment following cord transection was eliminated by hook removal. Apparently, separation of the last ganglion from the rest of the nerve cord blocked the excessive building that normally follows hook removal.

\section{DISCUSSION}

Larvae maintained in the laboratory rarely exhibited building activity so long as they occupied cases. When the cases were removed, they built new ones. It appears, then, that the stimulation provided by the case inhibits building activity. The extensive building that followed hook and hair removal indicates that stimulation of these structures constitutes an important part of the inhibitory mechanism.

The results of transection of the ventral nerve cord suggest that the sensory impulses from the hooks and hairs do not have to reach the anterior ganglia to exert their inhibitory effect. One is therefore led to conclude that the inhibitory action takes place at the individual ganglia. The following hypothesis is offered as a possible mechanism by which building activity is stimulated and inhibited.

The naked animal is assumed to be in a state of excitation as a result of impulses traveling forward from the several ganglia to the anterior regions. Possible sources of these impulses are discussed below. If the naked animal encounters a case and enters it, the sensory input derived from the case inhibits the emission of impulses from the ganglia and reduces the state of excitation. If the larva does not enter a case, its excitation induces building activity, which continues until sensory input from the new case is sufficient to reduce the excitation.

There are at least three possible sources for these postulated impulses from the ganglia. (1) They may be the result of endogenous activity within each ganglion. (2) Endogenous activity arising in the brain may send impulses to each ganglion, synapse there, and travel back unless inhibited by sensory input to the ganglion. (3) There may be receptors which are stimulated only when the animal is out of its case. In the remainder of the discussion it will be assumed, for the sake of conciseness, that the postulated impulses arise in the several ganglia.

Restating the hypothesis in compact form, building activity is stimulated by endogenous activity originating in the several segmental ganglia. Sensory input derived from a case inhibits such activity and thereby prevents building.

In view of the provisional nature of the long cases built after hook and hair removal, it seems possible that the first inhibitory action involving these structures may simply cause a transition to the definitive mode of building. Total inhibition of building activity might then involve finer discriminations in sensory input. However, such elaborations await further investigation.

Electrophysiological studies and more ablation experiments are now being planned to test the validity of the hypothesis. 


\section{ACKNOWLEDGMENTS}

I am deeply indebted to Professor Donald M. Maynard, Jr. for his advice and encouragement in this work. Dr. Herbert H. Ross of the Illinois Natural History Survey kindly checked the identification of the animals.

\section{LITERATURE CITED}

Balduf, W. V. 1939 The Bionomics of Entomophagous Insects, Part II. St. Louis: John S. Swift Co., Inc.

Betten, C. 1934 The caddis flies or Trichoptera of New York State. Bull. N. X. St. Mus., 292: $1-576$.

Copeland, M., and S. Crowell 1937 Observations and experiments on the case-building instinct of two species of Trichoptera. Psyche, Camb., Mass., 44: 125-131.

Cummins, K. W. 1961 The micro-distribution of the caddis-fly larvae Pycnopsyche lepida (Hagen) and Pycnopsyche guttifer (Walker) in a restricted portion of a small Michigan stream. Ph.D. dissertation. University of Michigan, Ann Arbor.

Diehm, Lore 1949 Zur Analyse des Köcherbaus der Phyryganeidenlarven. $Z$. vergl. Physiol., 31: 627-651.

Fankhauser, G, and L. E. Reik 1935 Experiments on the case building of the caddis-fly larva Neuronia postica Walker. Physiol. Zool., 8: 337-359.

Gorter, F. J. 1929 Experiments on the case building of a caddis worm (Limnephilus flavicornis Fabr.). Tijdschr. ned. dierk. Ver., 3. Ser., 1: 90-93.

Merrill, D. 1963 Factors governing case-building behavior of Trichopteran larvae. Amer. Zool., 3: 506 (Abstract).

Osborne, M. P., and L. H. Finlayson 1962 The structure and topography of stretch receptors in representatives of seven orders of insects. Quart. J. Micro. Sci., 103: 227-242.

Siegel, S. 1956 Nonparametric Statistics for the Behavioral Sciences. New York: McGrawHill Book Co., Inc.

PLATE 1

EXPLANATION OF FIGURES

Figures 4 to 7: Fifth instar larvae with cases.

4 Ptilostomis semifasciata.

5 Platycentropus radiatus

6 Limnephilus indivisus.

7 Pycnopsyche guttifer.

Figures 8 to 11: Long cases built following removal of anal hooks and posterior hair sensilla, compared with control cases.

8 Ptilostomis.

9 Platycentropus.

10 Limnephilus.

11 Pycnopsyche. 

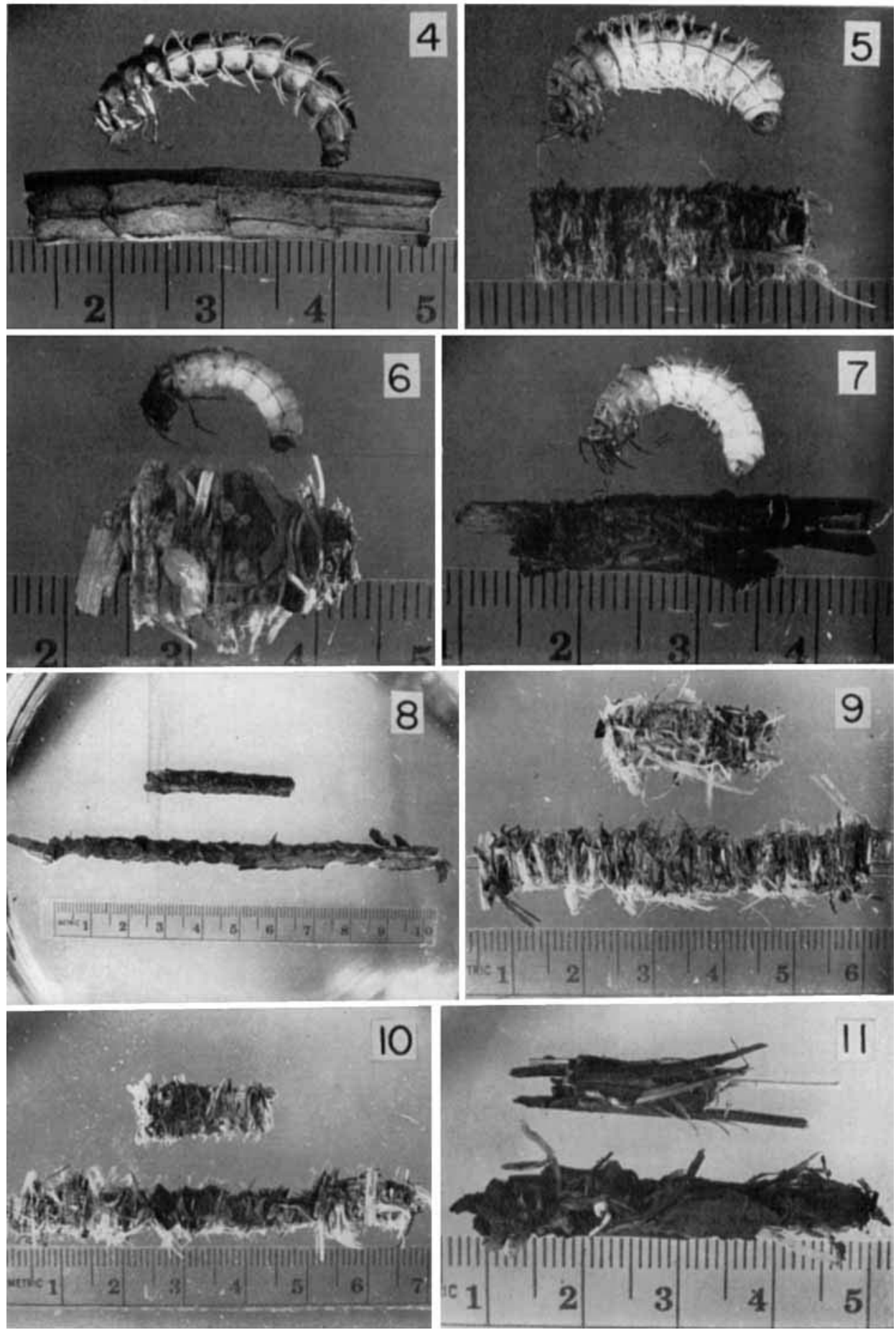